\title{
THE EFFECTS OF NATIONAL INSTITUTIONS AND COLLECTIVE BARGAINING ARRANGEMENTS ON JOB QUALITYIN FRONT-LINE SERVICE WORKPLACES
}

\author{
VIRGINIA DOELLGAST, URSULA HOLTGREWE, and STEPHEN DEERY*
}

\begin{abstract}
This paper analyzes the relationships among national institutions, collective bargaining arrangements, and job quality in call center workplaces, using establishment-level survey data obtained in 2003-2006 in five European coordinated market economies (CMEs) (Austria, Denmark, France, Germany, and Sweden) and three liberal market economies (LMEs) (Canada, the United States, and the United Kingdom). Overall, the authors find lower dismissal rates, more use of high-involvement management practices, and less performance monitoring in the CMEs, consistent with the notion that national institutions can influence employment practices even in more poorly regulated service workplaces. However, workplace-level collective bargaining arrangements and in-house (compared to outsourced) status also were associated with significantly higher measures of job quality across countries. Findings suggest that within CMEs, dual union/works council representation continues to provide important support for job security, participation, and discretion, but that outsourcing can effect a partial escape from this institution.
\end{abstract}

$\mathbf{I}_{\mathrm{r}}$ $\mathrm{n}$ the 1970s and 1980s, continental Europe enjoyed both steady economic growth and the expansion of high-quality jobs. Industry-level pay and job security agreements, strong employment protections, and broad co-determination rights precluded the cost-cutting strategies pursued in the United States and United Kingdom and encouraged investments in high pay and worker skills. In recent years, these national differences ap- pear to be eroding, as unions lose members and influence and as governments relax employment protection regulations. Today core sectors with strong unions and good working conditions are generating fewer new jobs than sectors without these protections.

In this paper, we ask whether national and collective bargaining institutions can encourage managers in front-line service workplaces to adopt employment practices

\footnotetext{
Technical University of Denmark, the Danish Center for Alternative Social Analysis, and the Call Center Research Association UK. The authors received substantial feedback on earlier drafts from Rosemary Batt and David Holman, as well as from participants in the Global Call Center Project meeting in Edinburgh, October 2006.

A data appendix with additional results, and copies of the computer programs used to generate the results presented in the paper, are available from the first author at Dept. of Management, London School of Economics, Houghton Street, London WC2A 2AE, U.K.; v.l.doellgast@lse.ac.uk.
} 
associated with high-quality jobs, defined as jobs with low dismissal rates, opportunities for participation and discretion, and limited performance monitoring. We focus on call centers because they are a setting where we might expect institutions to have weak effects on management strategy. The newness and mobility of call centers, the ease with which calls can be shifted between locations, and the growing prevalence of outsourcing have made it difficult for unions to organize these workplaces (Shire, Holtgrewe, and Kerst 2002; Holst 2008). However, call centers are also often based in industries with a strong union presence, such as telecommunications, and they have been the focus of both recent union organizing efforts and labor-management partnerships on work reorganization (Doellgast 2008; Taylor and Bain 2001). They thus provide a good setting for examining how differences in bargaining arrangements within and across countries affect job quality in new workplaces under strong pressures to cut costs and rationalize work.

The analysis is based on survey data from five coordinated market economies in continental Europe with strong labor laws and bargaining rights, extensive bargaining coverage, and industry-level bargaining structures (Austria, Denmark, France, Germany, and Sweden) and three liberal market economies with weak labor laws and bargaining rights, low bargaining coverage, and fragmented bargaining structures (the United States, the United Kingdom, and Canada). First, we ask whether measures of job quality vary systematically between countries associated with liberal and coordinated models of capitalism. Second, we analyze the relationship between workplace-level collective bargaining institutions and job quality. Here, we compare union effects in liberal market economies with both works council and union effects in coordinated market economies-in other words, we examine the effects of bargaining structure rather than just union presence. Third, we ask whether these institutional effects differ between in-house and outsourced call centers. Outsourcing is a common strategy used to segment call center work or to pursue a more cost-focused strategy, as it allows firms to avoid collective agreements or existing commitments to the work force (Walsh and Deery 2006); thus we might expect these workplaces to be the most likely place for convergence on low-quality jobs. Findings draw on data from the Global Call Center Project (Holman, Batt, and Holtgrewe 2007), which consists of identical establishment-level surveys of 1,734 call centers in the countries investigated here.

\section{Previous Research}

Job quality is typically viewed as consisting of extrinsic or economic outcomes, including high pay and job security (Kalleberg, Reskin, and Hudson 2000; McGovern, Smeaton, and Hill 2004), and outcomes that provide more intrinsic or indirect benefits, including participation in decision-making, discretion over tasks, and an absence of detailed monitoring and surveillance (Valverde, Ryan, and Gorjup 2007; Tilly 1997; Green 2005). Comparative researchers have argued that these measures of job quality are not simply a function of firm-level differences in strategy, technology, or human capital, but also are influenced by political and economic institutions outside the firm. Studies in the 1980s and 1990s showed that manufacturing firms in liberal market economies, such as the United States and United Kingdom, were more likely to pursue Taylorist models of work organization associated with high turnover, narrowly designed jobs, and intensive monitoring, while similar firms in European coordinated market economies such as Germany and Sweden invested in worker skills and adopted practices emphasizing internal flexibility (Lorenz 1992; Berggren 1992; Streeck 1984; Turner 1991; Wever 1995).

While there is broad consensus today that "national institutions matter" for job quality, researchers continue to debate exactly how they matter, or the mechanisms through which these institutions influence management decisions. One group of theories associated with the comparative capitalism literature emphasizes the embeddedness of employer strategies in complementary institutions at the national level. Employment practices that rely on high skills and worker autonomy are viewed as one outcome of 
national business systems or varieties of capitalism, which encourage employers to adopt long-term investment and market strategies (Hall and Soskice 2001; Whitley 1999). In contrast, political or power-based arguments advanced by industrial relations theorists hold that collective bargaining institutions play a central and unique role in outcomes, as they distribute bargaining power between different actors in the workplace and in society. High job quality in the coordinated market economies of "social Europe" is thus explained by these countries' traditions of strong labor unions, which have used extensive negotiating rights and high bargaining coverage to redistribute productivity gains to workers (Turner 1991).

These two perspectives differ in the role each attributes to collective bargaining as a central governance mechanism and explanation for cross-national variation in job quality. This distinction has become more meaningful in current debates concerning institutional change and liberalization in $\mathbf{E u}-$ rope (Streeck and Thelen 2005). Studies of work reorganization in the 1980 s and 1990 s were based primarily on matched case studies in export-oriented sectors that were embedded in national systems of complementary institutions and that had high bargaining coverage and union density. Today, collective bargaining arrangements are becoming increasingly heterogeneous within and between countries (Katz and Darbishire 2000), and may be viewed as a more immediate obstacle to widening management prerogative than other coordinating institutions, such as inter-firm relations (Hoepner 2007). The reach and organization of collective bargaining is likely to be more uneven in service workplaces, which tend to be newer and smaller than manufacturing establishments and which typically have lower union density and employ groups with low union affinity, such as minorities and students (Dolvik and Waddington 2004). Under these conditions, are firms in coordinated market economies more likely than those in liberal market economies to adopt employment practices associated with high-quality jobs, regardless of industry segment or collective representation? Or are "good jobs" primarily a feature of core workplaces in these countries with strong unions and works councils-in other words, is workplace-level collective bargaining a necessary condition for the positive worker outcomes traditionally associated with the social European model?

We contribute to these debates by comparing the effects of both national and collective bargaining institutions on employment practices in call centers-workplaces that have been a focus of recent efforts to restructure and segment customer service and sales in a variety of industries. In the following sections, we develop hypotheses based on the comparative capitalisms literature and power-based theories from the industrial relations literature.

National institutions and job quality. Comparative capitalism scholars view national economies as consisting of distinct configurations of institutions that generate or support a particular "logic" of action (Jackson and Deeg 2006:6). The varieties of capitalism approach, associated with the work of Hall and Soskice (2001), distinguishes between two groups of national economies, based on the forms of coordination used to solve transaction cost problems. In coordinated market economies, bank-based finance provides "patient capital" for long-term investments, stakeholder corporate governance systems support cooperative labor relations, and organized vocational training provides high industry- or firm-specific skills. Together, these institutions should support qualityfocused strategies: firms have incentives to make long-term commitments to employees and disincentives to exit from these commitments. In liberal market economies, the market plays a more central coordinating role in all of these areas, encouraging more unilateral management approaches and competitive strategies associated with cost-based competition and high external flexibility.

Other comparative capitalism theorists view institutions as the result of nationally specific historical trajectories. According to this view, distinct national patterns of production methods and vocational training differentiate coordinated economies (Maurice, Sellier, and Silvestre 1986), and varied 
labor law and union organization patterns differentiate liberal economies (Colvin 2006; Godard 2002). For example, U.K. legislation on working time and employment protection is increasingly influenced by EU social directives, which impose employer constraints not present in the United States.

Taken together, these theories predict that employment practices associated with high-quality jobs will differ across countries, but disagree on the extent of convergence between countries characterized by more liberal or coordinated institutions. We might expect a greater degree of convergence in service firms, as they tend to focus on national or local markets, are less likely than manufacturing firms to be covered by traditional vocational training and collective bargaining institutions, and are typically under strong pressures to reduce direct labor costs, given limited substitutability by capital. However, there is some evidence of cross-national variation in service management practices. For example, Finegold et al. (2000) found that German hotels adopted more job rotation and had lower employee turnover than hotels in the United Kingdom and United States, while Shire et al. (2002) and Doellgast (2008) found that German call centers designed jobs more broadly and monitored employees less intensively than call centers in the United Kingdom and United States.

This suggests that we can expect variation in the quality of call center jobs at the national level, but that there should be some systematic differences in outcomes between countries associated with coordinated and liberal market models. Thus:

Hypothesis 1: Call centers in coordinated market economies will have lower rates of dismissal, greater use of high-involvement work practices, and lower performance monitoring than those in the United States, while call centers in other liberal market economies will have practices similar to those in the United States.

Collective bargaining institutions and job quality. Political or power-based arguments advanced by industrial relations scholars hold that collective negotiations at the firm and workplace level are a central mechanism through which national institutions influence employment practices. This suggests two modifications to "national effects" arguments. First, workplaces with collective bargaining institutions should have different outcomes from workplaces without those institutions. Second, worker representatives in coordinated and liberal market economies should have different resources for influencing the three measures of job quality we examine here-dismissals, work organization, and performance monitoring.

In European coordinated market economies, the structure (not just the presence) of collective bargaining influences bargaining power. A key feature of industrial relations in these countries is the system of co-determination or consultation through works councils. Labor unions' primary responsibility has traditionally been to negotiate industry-level agreements on pay and working time with employers associations, while employee-elected works councils negotiate firm-and establishment-level agreements on such practices as the introduction of performance-based pay, the introduction and evaluation of teams, and the use of monitoring technologies. The combination of these workplace- and industry-level bargaining structures was believed to create "productive constraints" that foreclosed strategies to compete on the basis of low wages and high external flexibility in countries like Germany (Streeck 1991). In recent years, these boundaries have become increasingly blurred: negotiations over pay and working time have been decentralized to the establishment level across Europe due to the expansion of firm-level agreements and decline in bargaining coverage (Katz and Darbishire 2000), and works councils' ties with unions have weakened in many industries and countries. As a result, workplaces are increasingly covered by different combinations of union and works council agreements.

Each level of interest representation should, in turn, have distinct effects on job quality measures. Union agreements are often viewed as being encompassing within coordinated market economies or at least as having substantial spill-over effects on other firms. Thus, unions may have only weak effects on dismissals, as job security is enhanced by national employment protec- 
tion legislation. There is also little reason to expect union agreements to influence work design or performance monitoring, as unions typically do not have central responsibility for negotiating over these practices. In contrast, works councils may have a more direct effect on all measures of job quality, because they are typically responsible for negotiating agreements on such issues as work redesign and often play a role in approving or contesting hire and fire decisions.

These bodies thus have different bargaining roles and rights that may influence outcomes. However, the configuration of union and works council agreements should make the most crucial difference for bargaining power. Close relationships between unions and works councils have been viewed as important in encouraging unions to develop independent expertise to influence the construction of "best practices" at the firm level (Belanger, Giles, and Murray 2002). Works councils often rely on unions to provide legal and organizational resources, as well as to help coordinate the bargaining agenda across establishments in a firm and industry to foreclose competition for investment on the basis of wages and working conditions (Thelen 1991). This suggests that in coordinated market economies, collective bargaining should encourage the use of practices associated with good jobs; and, further, these effects should be strongest in establishments with both a union agreement and a works council. Doellgast (2008) found evidence of this stronger "dual representation" effect on employment practices in German call centers, which we expect to hold across the coordinated countries. Thus:

Hypothesis 2: In coordinated market economies, call centers with both a union and a works council agreement will have lower dismissal rates, greater use of high-involvement work practices, and lower performance monitoring than centers with no collective bargaining institutions.

Unions in liberal market economies rely on firm- or establishment-level bargaining structures and have more direct contact with workers through a shop steward and grievance system. They negotiate over pay, benefits, job security provisions, and due process, but they do not have formal rights to negotiate over the design of work and compensation. Thus, unions have primarily been able to influence extrinsic aspects of job quality, such as job security. Union presence has been found to be negatively associated with dismissals in both the United States and the United Kingdom (Shaw et al. 1998:198; Cully et al. 1999), which is often attributed to strong and institutionalized grievance procedures that provide a mechanism for challenging arbitrary decisions by managers.

In contrast, union presence in liberal market economies has been found to have either no effect or a negative effect on employment practices associated with intrinsic aspects of job quality, such as teamwork, work discretion, and monitoring (Wood 1996). Most studies from the United States show that workers in unionized workplaces are less satisfied than non-union workers with job content, supervision, and promotion opportunities. Hammer and Avgar (2005:243-44) summarized three possible explanations for these findings: first, unpleasant jobs are more likely than other jobs to attract unionization; second, management may increase production demands after unionization to compensate for higher labor costs; and third, unions may negotiate narrow job classifications and restrictive work rules that make it more difficult to implement high-involvement practices. In comparative perspective, these outcomes may be attributed to the narrow scope of bargaining rights in liberal market countries.

This suggests that collective bargaining will be associated with extrinsic rather than intrinsic job quality outcomes in liberal market economies:

Hypothesis 3: In liberal market economies, call centers with union agreements will have lower dismissal rates than those with no collective bargaining institutions. However, the work organization and performance monitoring practices adopted by unionized establishments will not significantly differ from those adopted by the other establishments.

Outsourcing and job quality. Institutional effects also may vary across industry segments that differ with respect to inherited bargaining structures, level of exposure to 
price-based competition, and degree of embeddedness in national systems of corporate governance and training. Subcontracting status, or whether firms handle calls in-house or subcontract this work to third-party providers, is one important factor distinguishing call center industry segments. Outsourced suppliers are newer, more volatile firms that are less likely to be covered by collective bargaining agreements (Holman, Batt, and Holtgrewe 2007).

Three characteristics of this business segment encourage the degradation of job quality and present distinct challenges to worker representatives seeking to improve workers' jobs. First, outsourced firms are often under substantial pressure to cut costs. Although a variety of factors affect the decision to outsource, studies have found that labor cost savings are often a central motivation (Harrison and Kelley 1993). By subcontracting out work, organizations can take advantage of lower wage rates without violating internal equity standards (Abraham 1990). Second, subcontractors' clients have an interest in closely monitoring subcontractors' work force and often require the outsourced supplier to meet strict performance standards (Walsh and Deery 2006; Schönauer 2008). This can contribute to work intensification, more rigid job descriptions, and less control over the timing and methods of work. Third, outsourcing may be used to check the growth of unions and to weaken the bargaining power of workers by moving operations outside the coverage of collective agreements and "escaping" traditional legal and negotiated constraints on the employment relationship (Pfeffer and Baron 1988; Doellgast and Greer 2007; Marginson, Sisson, and Arrowsmith 2003).

For these reasons, outsourcers are typically assumed to create lower-quality jobs than similar in-house firms. This view has been supported by several studies of service workplaces. Grugulis, Vincent, and Hebson (2003) showed that subcontracting increased monitoring and decreased discretion across job functions with different levels of complexity. Batt, Doellgast, and Kwon (2006) found that outsourced call centers in the United States used more electronic monitoring and had lower pay and discretion than similar inhouse centers. In an employee-level study, Walsh and Deery (2006) showed that the work force of a call center subcontractor for an Australian airline had lower pay, less job security, and a less developed internal labor market than its in-house work force.

These conditions in turn present multiple challenges to unions and other worker representatives. Union organizing is likely to require high efforts for uncertain rewardsleading to the paradox that those groups of workers with poor job quality who have the greatest need for unions are least likely to have access to them (Sydow 1997). Outsourced call centers typically have weaker collective bargaining institutions, and have proven more difficult to organize in both liberal and coordinated market economies. In Austria, the Netherlands, and France, sectoral collective agreements have been negotiated for subcontractors, although with weak terms and conditions, while elsewhere, only a minority of these workplaces are covered by firm-level agreements.

Thus, we expect that outsourced call centers will be less likely to adopt employment practices associated with high-quality jobs in both coordinated and liberal market economies:

Hypothesis 4: Outsourced call centers will have higher dismissal rates, more limited use of highinvolvement work practices, and higher performance monitoring than in-house centers.

In addition, we expect that both national and collective bargaining institutions will have either weaker or no effects on job quality in outsourced call centers, due to the relative newness of this sector and its possible use by companies to escape existing institutional constraints.

\section{Methods}

\section{Sample}

The sample is drawn from establishmentlevel surveys of call center managers conducted in eight countries: Austria, Denmark, France, Germany, Sweden, Canada, the United Kingdom, and the United States. 
Austria, Denmark, France, Germany, and Sweden are all coordinated market economies (CMEs) in northern and central Europe with high bargaining coverage, a tradition of industry-level bargaining between employer and union confederations, and a complementary system of works councils. Works councils in Germany and Austria have extensive co-determination rights over working time, payment methods, health and safety, and the introduction and use of equipment for monitoring employees. In Denmark, works councils do not have legally protected codetermination rights, but they play a similarly independent role in representing employee interests and negotiating over employment policies and practices (Jørgensen 2003). In France, works councils have weaker codetermination rights, but typically play an important consultation role, particularly with regard to financial and restructuring topics; and in Sweden, strong legal information, consultation, and co-determination rights are exercised primarily by labor unions with the support of works councils. As the characteristics of collective bargaining in France and Sweden are distinct from those in the other countries, we ran separate analyses excluding them. However, the key results with respect to bargaining structure effects were similar; thus, we include these countries for purposes of extending the scope and generalizability of findings.

In contrast, Canada, the United Kingdom, and the United States are all liberal market economies (LMEs) with low bargaining coverage and primarily firm-or establishment-level bargaining agreements (Godard 2002:251). Where unions are present, they represent employees through collective bargaining on pay, employment security, and seniority rights and through a shop steward system that enforces contract provisions. However, they have no formal rights to negotiate over work redesign, the introduction of new technology, or the design of compensation. While works councils are present in the United Kingdom and have been strengthened by a series of EU directives, they primarily play a weak consultation role (Hall and Terry 2004).

These surveys were based on a common template and conducted by separate coun- try teams as part of the eighteen-country Global Call Center Project. Samples were drawn from membership lists of employers associations and industry associations in most countries, due to the lack of official national statistics on call centers. The final sample included 1,734 establishments from the eight countries, but this number was reduced in the regressions to 1,441 (dismissals), 1,624 (high-involvement work organization), and 1,622 (performance management), due to missing data. ${ }^{1}$ Further information on survey procedures and response rates for each country survey is provided in the introduction to this symposium (Batt, Holman, and Holtgrewe).

\section{Measures}

Dependent variables. Our dependent variables include three measures of employment practices associated with job quality: the level of dismissals, high-involvement work organization, and performance monitoring. The dismissal ratemeasures the percentage of the core work force that was dismissed in the previous year. For the multivariate analyses, we used the square root of dismissals, which produced a more normal distribution of the outcome variable than a log transformation.

The high-involvement work organization scale includes measures assessing the degree to which work is designed to take advantage of employee skills and employee participation in decision-making. It includes the percentage of core employees in self-managed teams, in offline teams, with flexible job descriptions, and with access to flexible working arrangements. It also includes average employee discretion, measured using six items: the level of employee discretion over the daily work tasks employees perform; the tools, methods, or procedures they use; the pace or speed at which they work; what they say to the customer; their lunch and break schedule; and handling additional customer requests, measured on a five-point Likert scale.

\footnotetext{
${ }^{1}$ Means and standard deviations for all variables at the country level are provided in Appendix $\mathrm{E}$ in the introduction to this special issue (Batt, Holman, and Holtgrewe).
} 
Performance monitoringemploys eight-point scales, with values ranging from "never" to "daily," to measure three variables-how often employees are given statistics on performance, how often they are given general feedback on performance, and how often supervisors listen to calls-and a five-point Likert scale to measure the extent to which performance information was used to discipline employees. The work organization scale (Cronbach's alpha $=0.54$ ) and performance monitoring scale (Cronbach's alpha $=0.64$ ) were constructed by taking the average of standardized z-scores for each variable. We selected the variables in each scale based on categories derived from theory and past research, rather than by attempting to isolate an underlying common factor (Delery 1998). Thus, we do not assume that the practices are highly correlated with one another, but rather that when they are implemented together they likely signal a work environment that provides opportunities for participation and discretion.

We chose to analyze job quality in terms of three different outcomes rather than as one aggregated scale for several reasons. First, past research has found that managers often adopt seemingly contradictory practices aimed at simultaneously promoting commitment and cutting costs. For example, higher task discretion is often combined with work intensification and poor job security (Appelbaum and Batt 1994). These mixed or "hybrid" models may be particularly common in service organizations, which face the potentially conflicting goals of being both customer-oriented and cost-efficient (Korczynski 2002). Second, unions and works councils have different bargaining rights and forms of bargaining leverage over different kinds of management decisions. Thus, by analyzing them separately, we are able to distinguish between outcomes with stronger or weaker institutional effects.

Independent variables. We created five indicator variables to measure different collective bargaining arrangements in CMEs and LMEs. These were coded as 1 or 0 for the following categories: workplaces in coordinated market economies (a) with both a union agreement and a works council, (b) with a works council but no union agreement, and (c) with a union agreement but no works council; (d) workplaces in liberal market economies with a union agreement; and (e) workplaces in all countries with no collective bargaining. National setting is based on country indicators. Subcontracting status is measured as an indicator variable, coded 1 if the call center is operated as an in-house firm and 0 if it is a subcontractor.

Controlvariables. We control for differences in human capital, job type, industry, and organizational characteristics that may affect the employment practices firms adopt. An alternative explanation for why some countries and workplaces have higher job quality than others may be that firms in those settings enjoy a more educated pool of workers, or have adopted a production model that relies on higher overall skill levels. These factors may influence expected returns to investments from practices emphasizing worker discretion or participation and thereby affect employers' incentives to reduce transaction costs through, for example, internal labor markets or job security arrangements (Becker 1964). We include three variables for average educational level of the work force-(a) schooling through age 18, (b) schooling through university, and (c) (the reference category) schooling through age 16 or no education-and one variable measuring the number of weeks it takes an average worker to become proficient in the job.

Past research has found that sales-focused service interactions are associated with greater individualization of work and autonomy as well as higher employee burnout and turnover (Batt 1999). Thus, we control for centers in which the majority of calls are outbound. We also control for whether the center primarily serves large business customers, as service companies may adopt practices associated with high job quality for employees servicing market segments that promise high returns (Blutner, Brose, and Holtgrewe 2000). Two controls for industry segmenttelecommunications and banking - account for possible differences due to the history of strong regulation in both sectors. Finally, we 
include controls for organization size (total employment) and age (number of years since the center's establishment).

We experimented with a number of additional control variables in preliminary analyses, including other industry sectors, whether calls were predominantly salesfocused, whether the center served a national or international market, whether the center was part of a larger organization, and initial and ongoing training. However, as these did not add substantially to the explanatory power of the model, we omitted them from the final analysis.

\section{Results}

Collective bargainingstructure. Table 1 shows the percentage of establishments with different collective bargaining arrangements in the in-house and outsourced segments of each country. Representation was more extensive in the CMEs, where the majority of call centers and agents had collective agreements. However, there were striking differences between countries in each group. Bargaining coverage was greatest in Austria, France, and Sweden-all countries in which the state or employers associations have secured some form of mandatory extension of collective agreements. Sweden is unique in having $100 \%$ coverage of firms, although in France a very high percentage of the work force in surveyed call centers ( $94 \%)$ is covered by a collective agreement. Outsourced centers in Denmark and Germany had much more limited representation than in-house workplaces, with less than half as many establishments and workers covered by agreements. Again, this may be due to the lack of mandatory extension mechanisms, as the gap is narrower in Austria and France, while in Sweden the coverage of agents in in-house and outsourced operations is uniformly high. In addition, a higher proportion of subcontractors in these countries are covered by works council agreements alone, while in-house centers are more likely to have dual bargaining arrangements.

In two of the three LMEs, call centers were poorly represented-only $12 \%$ of the work force in Canada and $16 \%$ in the United States had union agreements-but in the United
Kingdom, almost half of the establishments and $71 \%$ of the work force were covered by an agreement, similar to rates for Denmark and Germany. Moreover, whereas Canada and the United States had negligible union presence in outsourced centers, the United Kingdom had higher coverage than Denmark and Germany, with $62 \%$ of agents covered by a union agreement.

Determinants of job quality. Multivariate analysis enables us to test the relationship between the different collective bargaining arrangements and job quality measures. Table 2 shows the means, standard deviations, and correlations for all variables. The shares of observations by country are as follows: Austria, 5\%; Denmark, 6\%; France, 12\%; Germany, 9\%; Sweden, 8\%; Canada, 22\%; the United Kingdom, 10\%; and the United States, $28 \%$.

Correlation results provide preliminary evidence that national setting, collective bargaining institutions, and subcontracting status are associated with variation in job quality. The presence of both a union and a works council in CMEs was correlated with all three measures of high-quality jobslower dismissal rates, a greater incidence of high-involvement work practices, and lower performance monitoring-while other collective bargaining arrangements showed more mixed results. In contrast, the presence of a union in the LMEs was only associated with lower dismissal rates. Outsourcing was correlated with higher dismissal rates and greater monitoring in the full sample.

The multivariate results for the relationships between our independent variables and the three measures of job quality are presented in Tables 3-5. In each table, Model 1 shows the results of hierarchical regressions that test the effects of national setting ( $\mathrm{Hy}$ pothesis 1); Model 2 adds variables measuring collective bargaining arrangements in CMEs (Hypothesis 2) and LMEs (Hypothesis 3); Model 3 includes variables for subcontracting status (Hypothesis 4); and Model 4 presents the full model with human capital controls. We then perform separate regressions on the outsourced call centers, to examine whether collective bargaining and national institu- 
Table 1. Collective Bargaining Structure by Country and Subcontracting Status.

\begin{tabular}{|c|c|c|c|c|c|c|}
\hline & Obs. & Union $+W C$ & Only $W C$ & Only Union & $\begin{array}{c}4 \\
\text { Some Form of } \\
\text { Bargaining } \\
\text { (Cols. } 1-3)\end{array}$ & $\begin{array}{c}5 \\
\text { \% Workers } \\
\text { with Some } \\
\text { Form of } \\
\text { Bargaining }\end{array}$ \\
\hline \multicolumn{7}{|l|}{ CMEs } \\
\hline $\begin{array}{l}\text { Austria } \\
\text { In-House } \\
\text { Outsourced }\end{array}$ & $\begin{array}{l}91 \\
57 \\
33\end{array}$ & $\begin{array}{r}38.46 \\
54.39 \\
9.09\end{array}$ & $\begin{array}{r}13.19 \\
15.79 \\
9.09\end{array}$ & $\begin{array}{l}20.88 \\
14.04 \\
33.33\end{array}$ & $\begin{array}{l}\mathbf{7 2 . 5 3} \\
84.21 \\
51.51\end{array}$ & $\begin{array}{l}\mathbf{7 7 . 4 9} \\
84.41 \\
64.10\end{array}$ \\
\hline $\begin{array}{l}\text { Denmark } \\
\text { In-House } \\
\text { Outsourced }\end{array}$ & $\begin{array}{r}118 \\
74 \\
21\end{array}$ & $\begin{array}{l}38.95 \\
45.95 \\
14.29\end{array}$ & $\begin{array}{r}10.53 \\
9.46 \\
14.29\end{array}$ & $\begin{array}{r}11.58 \\
13.51 \\
4.76\end{array}$ & $\begin{array}{l}\mathbf{6 1 . 0 5} \\
68.92 \\
\mathbf{3 3 . 3 4}\end{array}$ & $\begin{array}{l}72.01 \\
83.47 \\
35.00\end{array}$ \\
\hline $\begin{array}{l}\text { France } \\
\text { In-House } \\
\text { Outsourced }\end{array}$ & $\begin{array}{r}210 \\
150 \\
59\end{array}$ & $\begin{array}{l}\mathbf{6 2 . 2 0} \\
70.67 \\
40.68\end{array}$ & $\begin{array}{l}16.75 \\
12.00 \\
28.81\end{array}$ & $\begin{array}{r}8.13 \\
10.67 \\
1.69\end{array}$ & $\begin{array}{l}87.08 \\
93.33 \\
71.19\end{array}$ & $\begin{array}{l}\mathbf{9 4 . 2 2} \\
96.67 \\
90.10\end{array}$ \\
\hline $\begin{array}{l}\text { Germany } \\
\text { In-House } \\
\text { Outsourced }\end{array}$ & $\begin{array}{r}153 \\
48 \\
100\end{array}$ & $\begin{array}{l}22.52 \\
45.83 \\
11.00\end{array}$ & $\begin{array}{l}\mathbf{2 3 . 1 8} \\
35.42 \\
16.00\end{array}$ & $\begin{array}{l}3.31 \\
0.00 \\
5.00\end{array}$ & $\begin{array}{l}49.01 \\
81.25 \\
32.00\end{array}$ & $\begin{array}{l}76.33 \\
84.10 \\
42.45\end{array}$ \\
\hline $\begin{array}{l}\text { Sweden } \\
\text { In-House } \\
\text { Outsourced }\end{array}$ & $\begin{array}{r}139 \\
102 \\
32\end{array}$ & $\begin{array}{l}49.25 \\
51.96 \\
40.63\end{array}$ & $\begin{array}{l}- \\
- \\
-\end{array}$ & $\begin{array}{l}\mathbf{5 0 . 7 5} \\
48.04 \\
59.38\end{array}$ & $\begin{array}{l}100.00 \\
100.00 \\
100.00\end{array}$ & $\begin{array}{l}100.00 \\
100.00 \\
100.00\end{array}$ \\
\hline \multicolumn{7}{|l|}{ LMEs } \\
\hline $\begin{array}{l}\text { Canada } \\
\text { In-House } \\
\text { Outsourced }\end{array}$ & $\begin{array}{l}387 \\
203 \\
167\end{array}$ & $\begin{array}{l}- \\
- \\
-\end{array}$ & $\begin{array}{l}- \\
- \\
-\end{array}$ & $\begin{array}{r}16.19 \\
21.18 \\
8.38\end{array}$ & $\begin{array}{r}16.19 \\
21.18 \\
8.38\end{array}$ & $\begin{array}{r}11.90 \\
17.92 \\
8.02\end{array}$ \\
\hline $\begin{array}{l}\text { U.K. } \\
\text { In-House } \\
\text { Outsourced }\end{array}$ & $\begin{array}{r}167 \\
120 \\
43\end{array}$ & $\begin{array}{l}- \\
- \\
-\end{array}$ & $\begin{array}{l}- \\
- \\
-\end{array}$ & $\begin{array}{l}\mathbf{4 6 . 0 1} \\
\mathbf{5 5 . 8 3} \\
18.60\end{array}$ & $\begin{array}{l}\mathbf{4 6 . 0 1} \\
55.83 \\
18.60\end{array}$ & $\begin{array}{l}71.06 \\
75.30 \\
62.36\end{array}$ \\
\hline $\begin{array}{l}\text { U.S. } \\
\text { In-House } \\
\text { Outsourced }\end{array}$ & $\begin{array}{r}464 \\
398 \\
64\end{array}$ & $\begin{array}{l}- \\
-\end{array}$ & $\begin{array}{l}- \\
- \\
-\end{array}$ & $\begin{array}{r}9.09 \\
10.30 \\
1.56\end{array}$ & $\begin{array}{r}9.09 \\
10.30 \\
1.56\end{array}$ & $\begin{array}{r}16.00 \\
20.53 \\
1.04\end{array}$ \\
\hline
\end{tabular}

${ }^{a}$ Number of observations differs between the full dataset and the in-house and outsourced categories due to missing data on subcontracting status.

bBased on the total reported number of full-time and part-time agents, including temporary workers.

'U.K. call centers in our sample also had works councils; however, we do not include them here, as our comparison focuses on equivalent forms of collective bargaining between "coordinated market" and "liberal market" countries.

tions are associated with job quality measures in these workplaces. The reference group for collective bargaining effects is centers with no bargaining; and the reference for country effects is the United States. We use left-censored Tobit analysis for dismissal rates, because turnover truncated at 0 (Maddala 1992), and we use OLS regression for work practices and performance monitoring.

Table 3 provides information on the factors affecting dismissal rates. First, patterns at the national level do not show clear differences between CMEs and LMEs. The United States had significantly higher dismissal rates than all other countries. A comparison of coefficients demonstrates that while Canada had higher dismissal rates than Austria, France, and Germany, the United Kingdom's dismissal rates were not different from those in most CMEs (with the exception of Austria), and Denmark had significantly higher dismissal rates than Austria, France, and Germany. Thus, the United Kingdom and Denmark appear to be outliers in their respective groups. Second, collective bargaining influenced outcomes in each group of countries: significantly lower dismissals were associated with the joint presence of a union and a works council in the CMEs and with the presence of a union in LMEs. Lower 
Table 2. Means, Standard Deviations, and Correlations.

\begin{tabular}{|c|c|c|c|c|c|c|c|c|c|c|c|c|c|c|c|c|c|c|c|c|c|c|c|c|c|c|}
\hline & & Mean & S.D. & 1 & 2 & 3 & 4 & 5 & 6 & 7 & 8 & 9 & 10 & 11 & 12 & 13 & 14 & 15 & 16 & 17 & 18 & 19 & 20 & 21 & 22 & 23 \\
\hline 1 & Dismissal Rate (Sgrt) & 1.57 & 1.74 & & & & & & & & & & & & & & & & & & & & & & & \\
\hline 2 & HIWPs & 0.04 & -0.61 & -0.28 & & & & & & & & & & & & & & & & & & & & & & \\
\hline 3 & Monitoring & -0.07 & 0.69 & 0.35 & -0.27 & & & & & & & & & & & & & & & & & & & & & \\
\hline 4 & CME: Union \& WC & 0.18 & 0.38 & -0.23 & 0.18 & -0.25 & & & & & & & & & & & & & & & & & & & & \\
\hline 5 & CME: WC Only & 0.05 & 0.23 & -0.07 & 0.03 & -0.13 & -0.11 & & & & & & & & & & & & & & & & & & & \\
\hline 6 & CME: Union Only & 0.07 & 0.25 & -0.11 & 0.17 & -0.14 & -0.13 & -0.07 & & & & & & & & & & & & & & & & & & \\
\hline 7 & LME: Union & 0.10 & 0.30 & -0.09 & -0.08 & 0.04 & -0.16 & -0.08 & -0.09 & & & & & & & & & & & & & & & & & \\
\hline 8 & Austria & 0.05 & 0.22 & -0.09 & 0.05 & -0.09 & 0.11 & 0.08 & 0.14 & -0.08 & & & & & & & & & & & & & & & & \\
\hline 9 & Denmark & 0.06 & 0.23 & -0.03 & -0.01 & -0.13 & 0.14 & 0.06 & 0.04 & -0.08 & -0.06 & & & & & & & & & & & & & & & \\
\hline 10 & France & 0.12 & 0.33 & -0.20 & 0.08 & -0.12 & 0.45 & 0.18 & 0.02 & -0.13 & -0.09 & -0.09 & & & & & & & & & & & & & & \\
\hline 11 & Germany & 0.09 & 0.29 & -0.03 & 0.12 & -0.16 & 0.04 & 0.24 & -0.04 & -0.11 & -0.07 & -0.08 & -0.12 & & & & & & & & & & & & & \\
\hline 12 & Sweden & 0.08 & 0.27 & -0.10 & 0.24 & -0.18 & 0.25 & -0.07 & 0.49 & -0.10 & -0.07 & -0.07 & -0.11 & -0.09 & & & & & & & & & & & & \\
\hline 13 & Canada & 0.22 & 0.41 & 0.08 & -0.13 & 0.22 & -0.25 & -0.13 & -0.15 & 0.08 & -0.12 & -0.13 & -0.20 & -0.17 & -0.15 & & & & & & & & & & & \\
\hline 14 & U.K. & 0.10 & 0.30 & -0.07 & -0.06 & 0.03 & -0.16 & -0.08 & -0.09 & 0.39 & -0.08 & -0.08 & -0.13 & -0.11 & -0.10 & -0.18 & & & & & & & & & & \\
\hline 15 & In-House & 0.69 & 0.46 & -0.16 & 0.05 & -0.18 & 0.13 & -0.06 & -0.01 & 0.13 & -0.03 & 0.04 & 0.04 & -0.25 & 0.04 & -0.17 & 0.03 & & & & & & & & & \\
\hline 16 & Edu: $<18$ & 0.48 & 0.50 & 0.06 & -0.06 & 0.06 & -0.06 & -0.10 & 0.01 & 0.03 & -0.16 & 0.16 & -0.14 & -0.18 & 0.10 & 0.38 & -0.13 & -0.03 & & & & & & & & \\
\hline 17 & Edu: University & 0.23 & 0.42 & -0.14 & 0.14 & -0.10 & 0.15 & 0.00 & 0.05 & -0.03 & -0.07 & -0.09 & 0.38 & -0.17 & 0.04 & -0.13 & 0.04 & 0.11 & -0.52 & & & & & & & \\
\hline 18 & Wks to Be Proficient & 18.64 & 17.72 & -0.13 & 0.08 & -0.09 & -0.01 & -0.05 & -0.06 & 0.15 & -0.08 & -0.02 & -0.04 & -0.03 & -0.04 & 0.07 & 0.14 & 0.14 & 0.02 & 0.02 & & & & & & \\
\hline 19 & Inbound & 0.79 & 0.40 & -0.18 & 0.03 & -0.17 & 0.12 & 0.01 & 0.00 & 0.09 & -0.10 & 0.03 & 0.02 & -0.10 & 0.00 & -0.05 & 0.05 & 0.33 & 0.02 & -0.01 & 0.16 & & & & & \\
\hline 20 & Large Business & 0.21 & 0.41 & 0.03 & 0.07 & -0.06 & -0.10 & -0.03 & 0.03 & -0.06 & -0.03 & -0.07 & -0.06 & 0.07 & 0.03 & 0.01 & -0.02 & -0.14 & -0.06 & 0.08 & -0.03 & -0.18 & & & & \\
\hline 21 & Telecom & 0.21 & 0.41 & -0.07 & -0.04 & -0.03 & 0.12 & 0.03 & -0.01 & -0.07 & -0.05 & 0.01 & 0.11 & 0.00 & -0.01 & -0.04 & 0.00 & 0.10 & -0.03 & 0.12 & 0.09 & 0.09 & -0.07 & & & \\
\hline 22 & Banking & 0.29 & 0.46 & 0.07 & 0.00 & 0.05 & -0.05 & -0.03 & -0.07 & -0.01 & -0.05 & -0.06 & -0.02 & 0.01 & -0.07 & -0.11 & -0.15 & 0.04 & -0.01 & -0.04 & -0.04 & 0.02 & 0.02 & -0.33 & & \\
\hline 23 & Employment (ln) & 4.01 & 1.36 & 0.31 & -0.40 & 0.37 & -0.07 & -0.01 & -0.19 & 0.07 & -0.03 & -0.11 & -0.08 & -0.07 & -0.18 & 0.13 & 0.07 & -0.12 & 0.02 & -0.07 & -0.01 & 0.01 & -0.08 & 0.06 & 0.02 & \\
\hline 24 & Age $(\ln )$ & 2.32 & 0.68 & -0.04 & -0.01 & -0.02 & -0.06 & -0.03 & -0.07 & -0.02 & -0.06 & -0.10 & -0.04 & -0.13 & 0.01 & -0.05 & -0.11 & 0.12 & -0.03 & 0.02 & 0.10 & 0.03 & $0.01-$ & -0.07 & 0.07 & 0.01 \\
\hline
\end{tabular}

Note: significant at $\mathrm{p}<.05$ if value $>.05$. 
Table 3. Unstandardized Tobit Estimates for Dismissal Rates. (standard errors in parentheses)

\begin{tabular}{|c|c|c|c|c|c|}
\hline & Model 1 & Model 2 & Model 3 & Model 4 & Outsourced \\
\hline \multicolumn{6}{|l|}{ Collective Bargaining } \\
\hline CME: Union \& WC & & $\begin{array}{c}-0.865^{* *} \\
(0.339)\end{array}$ & $\begin{array}{l}-0.687^{* *} \\
(0.343)\end{array}$ & $\begin{array}{l}-0.712^{* *} \\
(0.340)\end{array}$ & $\begin{array}{c}-1.142^{* *} \\
(0.569)\end{array}$ \\
\hline CME: WC Only & & $\begin{array}{l}-0.141 \\
(0.400)\end{array}$ & $\begin{array}{c}-0.055 \\
(0.400)\end{array}$ & $\begin{array}{c}-0.112 \\
(0.397)\end{array}$ & $\begin{array}{c}-0.696 \\
(0.562)\end{array}$ \\
\hline CME: Union Only & & $\begin{array}{l}-0.448 \\
(0.435)\end{array}$ & $\begin{array}{c}-0.342 \\
(0.435)\end{array}$ & $\begin{array}{c}-0.360 \\
(0.432)\end{array}$ & $\begin{array}{c}-1.398^{* *} \\
(0.689)\end{array}$ \\
\hline LME: Union & & $\begin{array}{l}-1.335^{* * *} \\
(0.238)\end{array}$ & $\begin{array}{l}-1.237 * * * \\
(0.239)\end{array}$ & $\begin{array}{l}-1.180^{* * *} \\
(0.238)\end{array}$ & $\begin{array}{l}-0.490 \\
(0.555)\end{array}$ \\
\hline \multicolumn{6}{|l|}{ Country } \\
\hline Austria & $\begin{array}{l}-2.433^{* * * *} \\
(0.395)\end{array}$ & $\begin{array}{l}-1.982 * * * \\
(0.476)\end{array}$ & $\begin{array}{l}-2.152 * * * \\
(0.478)\end{array}$ & $\begin{array}{l}-2.282 * * * \\
(0.480)\end{array}$ & $\begin{array}{l}-2.942^{* * *} \\
(0.816)\end{array}$ \\
\hline Denmark & $\begin{array}{l}-1.238^{* * *} \\
(0.321)\end{array}$ & $\begin{array}{c}-0.882 * * \\
(0.380)\end{array}$ & $\begin{array}{l}-1.013^{* * *} \\
(0.382)\end{array}$ & $\begin{array}{c}-0.987^{* *} \\
(0.385)\end{array}$ & $\begin{array}{l}-2.189^{* * *} \\
(0.716)\end{array}$ \\
\hline France & $\begin{array}{l}-2.791 * * * \\
(0.250)\end{array}$ & $\begin{array}{l}-2.276^{* * *} \\
(0.373)\end{array}$ & $\begin{array}{l}-2.471^{* * *} \\
(0.378)\end{array}$ & $\begin{array}{c}-2.175^{* * *} \\
(0.384)\end{array}$ & $\begin{array}{l}-2.058^{* * *} \\
(0.645)\end{array}$ \\
\hline Germany & $\begin{array}{l}-1.705^{* * *} \\
(0.282)\end{array}$ & $\begin{array}{l}-1.534 * * * \\
(0.314)\end{array}$ & $\begin{array}{c}-1.839 * * * \\
(0.329)\end{array}$ & $\begin{array}{c}-1.913^{* * * *} \\
(0.334)\end{array}$ & $\begin{array}{l}-1.649^{* * * *} \\
(0.459)\end{array}$ \\
\hline Sweden & $\begin{array}{l}-1.927 * * * \\
(0.301)\end{array}$ & $\begin{array}{l}-1.334 * * * \\
(0.468)\end{array}$ & $\begin{array}{c}-1.559^{* * *} \\
(0.473)\end{array}$ & $\begin{array}{c}-1.456^{* * *} \\
(0.473)\end{array}$ & $\begin{array}{c}-0.748 \\
(0.811)\end{array}$ \\
\hline Canada & $\begin{array}{c}-0.910^{* * *} \\
(0.191)\end{array}$ & $\begin{array}{c}-0.811 * * * \\
(0.189)\end{array}$ & $\begin{array}{c}-0.951^{* * *} \\
(0.194)\end{array}$ & $\begin{array}{c}-0.840^{* * *} \\
(0.208)\end{array}$ & $\begin{array}{l}-1.537^{* * *} \\
(0.409)\end{array}$ \\
\hline U.K. & $\begin{array}{l}-1.876^{* * *} \\
(0.257)\end{array}$ & $\begin{array}{l}-1.413^{* * *} \\
(0.265)\end{array}$ & $\begin{array}{l}-1.507 * * * \\
(0.266)\end{array}$ & $\begin{array}{l}-1.374 * * * \\
(0.268)\end{array}$ & $\begin{array}{l}-1.772^{* * *} \\
(0.495)\end{array}$ \\
\hline \multicolumn{6}{|l|}{ Subcontracting } \\
\hline In-House & & & $\begin{array}{l}-0.510^{* * *} \\
(0.165)\end{array}$ & $\begin{array}{l}-0.417^{* *} \\
(0.165)\end{array}$ & \\
\hline \multicolumn{6}{|l|}{ Human Capital Controls } \\
\hline Edu: $<18$ & & & & $\begin{array}{c}-0.159 \\
(0.185)\end{array}$ & $\begin{array}{c}0.219 \\
(0.339)\end{array}$ \\
\hline Edu: University & & & & $\begin{array}{l}-0.617^{* * *} \\
(0.218)\end{array}$ & $\begin{array}{c}-0.219 \\
(0.430)\end{array}$ \\
\hline \multirow[t]{2}{*}{ Weeks to Be Proficient } & & & & $\begin{array}{l}-0.012^{* * *} \\
(0.004)\end{array}$ & $\begin{array}{l}-0.021^{* * *} \\
(0.007)\end{array}$ \\
\hline & & & & & Continued \\
\hline
\end{tabular}

dismissal rates were also recorded in in-house call centers; and including subcontracting status in the model diminished the size, but not the significance, of the LME union effect (Model 3). In outsourced centers, country effects were similar, with the exception of Sweden, where dismissal rates in outsourced centers were similar to or higher than rates in the LMEs, and Denmark, where they were similar to rates in the other CMEs. However, we find a different pattern of bargaining effects: in CMEs, both the combined presence of a union and a works council and the presence of a union alone were associated with reduced dismissals, while union presence had no effect in LMEs.

Table 4 examines variables associated with the adoption of high-involvement work practices. Again, there was some difference between CMEs and LMEs, but this did not hold for all countries. Call centers in Austria, Germany, and Sweden reported a significantly higher incidence of these practices than did the LMEs; however, France and Denmark 
Table 3. Continued.

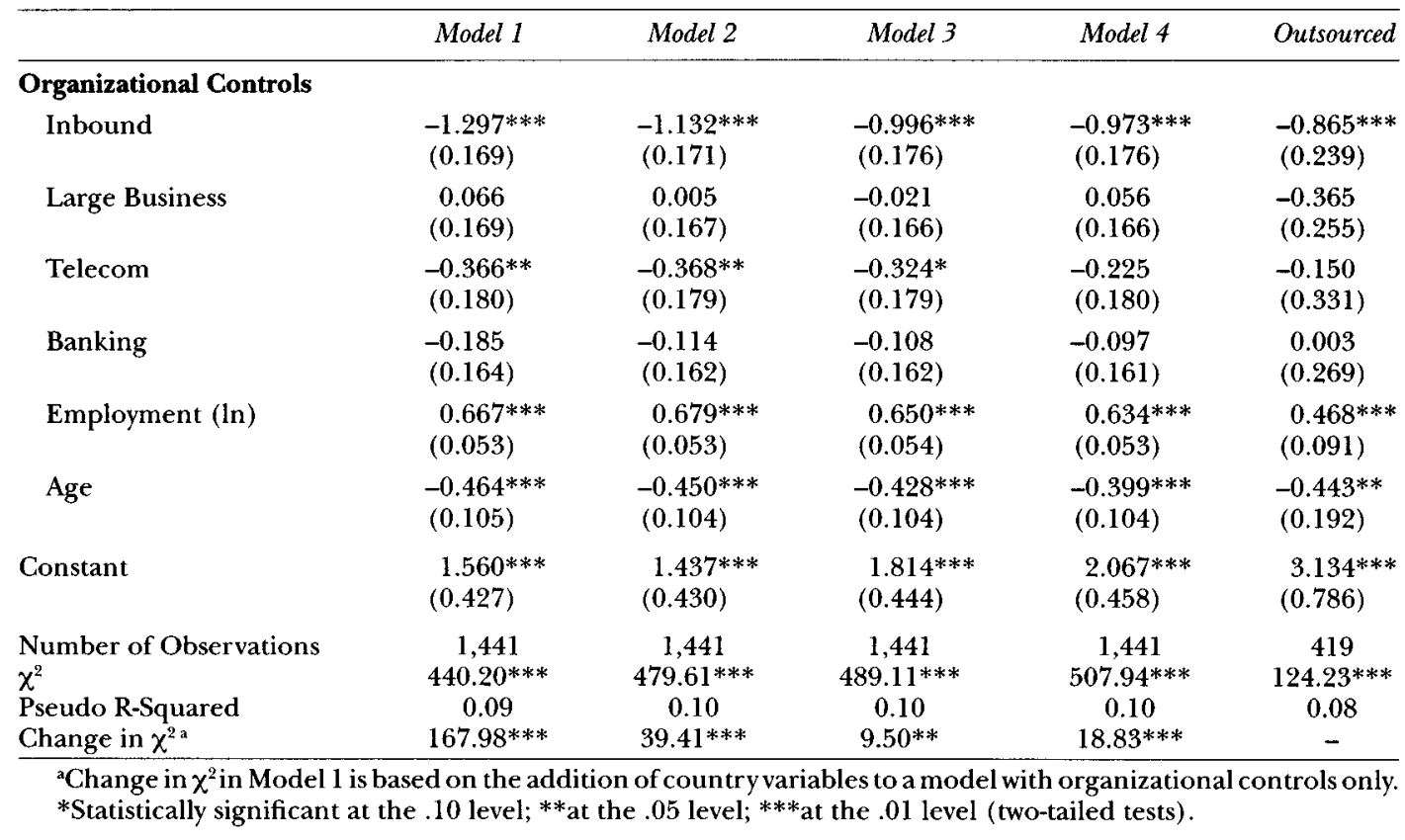

had rates of adoption similar to those of the LMEs. Collective bargaining effects again differ: the joint presence of a union and a works council in CMEs was associated with a greater use of high-involvement practices, but no effects are found for the lone presence of either a union or a works council in CMEs, or for union presence in LMEs. Finally, in-house centers did not use more of these practices, and including subcontracting status did not significantly change the R-square (Model 3). The analysis of the outsourced sample shows some differences in institutional effects. In Sweden, rates of adoption were similar to those in the LMEs; and in CMEs, use of these practices was higher in centers with a union agreement only, but not in those with just a works council or dual bargaining.

The third measure of job quality was performance monitoring (Table 5). Monitoring was significantly lower among call centers in all CMEs and the United Kingdom than in the United States and Canada. However, U.K. centers also had significantly higher rates of monitoring than all of the CMEs, with the exception of France, which also had higher monitoring rates than the other CMEs. Both the United Kingdom and France are thus outliers in their respective groups. Again, the combined presence of a union and a works council agreement in CMEs was associated with lower rates of performance monitoring, while union representation in the LMEs had no effect. However, in CMEs, the presence of a works council alone also reduced monitoring rates, while union presence alone had no effect. In-house centers used less performance monitoring, and the inclusion of subcontracting status significantly increased the R-square value and reduced the size and statistical significance of collective bargaining effects (Model 3). In the sample of outsourced centers, institutional effects were similar, although France is not significantly different from the United States or United Kingdom and the joint presence of a union and works council agreement in CMEs was not associated with reduced monitoring.

Across the three outcome measures, the addition of both country indicators (Model 1) and collective bargaining indicators (Model 2) significantly increased the Chi-square for dismissals and R-square for the other outcomes, suggesting that each set of institu- 
Table 4. Unstandardized OLS Estimates for High-Involvement Work Practices. (standard errors in parentheses)

\begin{tabular}{|c|c|c|c|c|c|}
\hline & Model 1 & Model 2 & Model 3 & Model 4 & Outsourced \\
\hline \multicolumn{6}{|l|}{$\overline{\text { Collective Bargaining }}$} \\
\hline CME: Union \& WC & & $\begin{array}{l}0.182 * * * \\
(0.063)\end{array}$ & $\begin{array}{l}0.173 * * * \\
(0.064)\end{array}$ & $\begin{array}{l}0.173^{* * * *} \\
(0.063)\end{array}$ & $\begin{array}{c}0.140 \\
(0.109)\end{array}$ \\
\hline CME: WC Only & & $\begin{array}{c}0.072 \\
(0.074)\end{array}$ & $\begin{array}{c}0.067 \\
(0.075)\end{array}$ & $\begin{array}{c}0.084 \\
(0.074)\end{array}$ & $\begin{array}{c}0.034 \\
(0.111)\end{array}$ \\
\hline CME: Union Only & & $\begin{array}{c}0.124 \\
(0.079)\end{array}$ & $\begin{array}{c}0.119 \\
(0.079)\end{array}$ & $\begin{array}{c}0.116 \\
(0.078)\end{array}$ & $\begin{array}{c}0.223^{*} \\
(0.130)\end{array}$ \\
\hline LME: Union & & $\begin{array}{c}-0.032 \\
(0.049)\end{array}$ & $\begin{array}{c}-0.038 \\
(0.049)\end{array}$ & $\begin{array}{c}-0.051 \\
(0.049)\end{array}$ & $\begin{array}{c}-0.042 \\
(0.124)\end{array}$ \\
\hline \multicolumn{6}{|l|}{ Country } \\
\hline Austria & $\begin{array}{l}0.257 * * * \\
(0.068)\end{array}$ & $\begin{array}{c}0.139^{*} \\
(0.082)\end{array}$ & $\begin{array}{c}0.149^{*} \\
(0.083)\end{array}$ & $\begin{array}{c}0.199 * * \\
(0.082)\end{array}$ & $\begin{array}{l}0.407 * * * \\
(0.140)\end{array}$ \\
\hline Denmark & $\begin{array}{c}0.009 \\
(0.065)\end{array}$ & $\begin{array}{c}-0.091 \\
(0.074)\end{array}$ & $\begin{array}{l}-0.083 \\
(0.075)\end{array}$ & $\begin{array}{c}-0.099 \\
(0.075)\end{array}$ & $\begin{array}{c}-0.006 \\
(0.150)\end{array}$ \\
\hline France & $\begin{array}{l}0.219 * * * \\
(0.047)\end{array}$ & $\begin{array}{c}0.075 \\
(0.071)\end{array}$ & $\begin{array}{c}0.086 \\
(0.072)\end{array}$ & $\begin{array}{c}-0.007 \\
(0.073)\end{array}$ & $\begin{array}{c}0.208 \\
(0.139)\end{array}$ \\
\hline Germany & $\begin{array}{l}0.320^{* * * *} \\
(0.054)\end{array}$ & $\begin{array}{l}0.249 * * * \\
(0.062)\end{array}$ & $\begin{array}{l}0.267^{* * *} \\
(0.065)\end{array}$ & $\begin{array}{c}0.313^{* * *} \\
(0.066)\end{array}$ & $\begin{array}{l}0.371^{* * *} \\
(0.101)\end{array}$ \\
\hline Sweden & $\begin{array}{l}0.490^{* * *} \\
(0.057)\end{array}$ & $\begin{array}{l}0.327^{* * *} \\
(0.086)\end{array}$ & $\begin{array}{l}0.338^{* * *} \\
(0.087)\end{array}$ & $\begin{array}{l}0.301^{* * *} \\
(0.087)\end{array}$ & $\begin{array}{c}0.197 \\
(0.169)\end{array}$ \\
\hline Canada & $\begin{array}{c}0.025 \\
(0.041)\end{array}$ & $\begin{array}{c}0.023 \\
(0.041)\end{array}$ & $\begin{array}{c}0.032 \\
(0.042)\end{array}$ & $\begin{array}{c}-0.014 \\
(0.044)\end{array}$ & $\begin{array}{c}0.118 \\
(0.091)\end{array}$ \\
\hline U.K. & $\begin{array}{c}0.065 \\
(0.053)\end{array}$ & $\begin{array}{c}0.075 \\
(0.056)\end{array}$ & $\begin{array}{c}0.080 \\
(0.056)\end{array}$ & $\begin{array}{c}0.042 \\
(0.056)\end{array}$ & $\begin{array}{c}0.049 \\
(0.112)\end{array}$ \\
\hline \multicolumn{6}{|l|}{ Subcontracting } \\
\hline In-House & & & $\begin{array}{c}0.031 \\
(0.034)\end{array}$ & $\begin{array}{c}0.007 \\
(0.034)\end{array}$ & \\
\hline \multicolumn{6}{|l|}{ Human Capital Controls } \\
\hline Edu: $<18$ & & & & $\begin{array}{c}0.091^{* *} \\
(0.038)\end{array}$ & $\begin{array}{c}-0.004 \\
(0.072)\end{array}$ \\
\hline Edu: University & & & & $\begin{array}{l}0.224^{* * *} \\
(0.043)\end{array}$ & $\begin{array}{c}0.134 \\
(0.091)\end{array}$ \\
\hline Weeks to Be Proficient & & & & $\begin{array}{l}0.003 * * * \\
(0.001)\end{array}$ & $\begin{array}{c}0.002 \\
(0.001)\end{array}$ \\
\hline
\end{tabular}

tional variables contributed meaningfully to improved job quality; the size and significance of change in explained variance, however, were more substantial for the country indicators. A number of the control variables were also statistically significant. The human capital variables were strongly associated with higher job quality across outcomes and increased the variance explained for both dismissals and high-involvement practices (Model 4). The addition of human capital controls did not decrease the significance of collective bargaining or country effects on job quality measures, with one exception: the difference in dismissal rates between Denmark and the United States declined in significance when Denmark's higher human capital measure was accounted for. Taken together, these findings suggest that differences in outcomes between workplaces with different collective bargaining arrangements or in different countries are poorly explained by variation in education and training levelsalthough the variables used here may also not 
Table 4. Continued.

\begin{tabular}{lccccc}
\hline & Model 1 & Model 2 & Model 3 & Model 4 & Outsourced \\
\hline Organizational Controls & & & & & \\
Inbound & $0.093^{* * *}$ & $0.068^{*}$ & $0.060^{*}$ & 0.054 & $0.130^{* *}$ \\
& $(0.034)$ & $(0.035)$ & $(0.036)$ & $(0.036)$ & $(0.053)$ \\
Large Business & $0.066^{*}$ & $0.070^{* *}$ & $0.072^{* *}$ & 0.051 & 0.070 \\
& $(0.034)$ & $(0.034)$ & $(0.034)$ & $(0.034)$ & $(0.054)$ \\
Telecom & -0.032 & -0.045 & -0.048 & $-0.080^{* *}$ & -0.074 \\
& $(0.036)$ & $(0.036)$ & $(0.036)$ & $(0.036)$ & $(0.072)$ \\
Banking & 0.034 & 0.029 & 0.029 & 0.026 & -0.028 \\
& $(0.033)$ & $(0.033)$ & $(0.033)$ & $(0.033)$ & $(0.058)$ \\
Employment (In) & $-0.150^{* * *}$ & $-0.153^{* * *}$ & $-0.151^{* * *}$ & $-0.147^{* * *}$ & $-0.129^{* * *}$ \\
& $(0.010)$ & $(0.010)$ & $(0.011)$ & $(0.010)$ & $(0.019)$ \\
Age & 0.023 & 0.021 & 0.020 & 0.010 & 0.029 \\
& $(0.021)$ & $(0.021)$ & $(0.021)$ & $(0.021)$ & $(0.041)$ \\
Constant & $0.381^{* * *}$ & $0.425^{* * *}$ & $0.400^{* * *}$ & $0.310^{* * *}$ & $0.148^{*}$ \\
& $(0.086)$ & $(0.087)$ & $(0.091)$ & $(0.093)$ & $(0.170)$ \\
Number of Observations & 1,624 & 1,624 & 1,624 & 1,624 & 503 \\
F Ratio & $35.13 * * *$ & $27.50^{* * *}$ & $26.01^{* * *}$ & $25.07^{* * *}$ & $7.52^{* * *}$ \\
R-Square & 0.22 & 0.23 & 0.23 & 0.25 & 0.24 \\
Adj. R-Squared & 0.21 & 0.22 & 0.22 & 0.24 & 0.21 \\
F for Change in $\mathrm{R}^{2 \mathrm{a}}$ & $16.34^{* * *}$ & $3.55^{* * *}$ & 1.25 & $9.64^{* * *}$ & - \\
\hline
\end{tabular}

${ }^{2}$ Change in $\mathrm{R}^{2}$ in Model 1 is based on the addition of country variables to a model with organizational controls only.

*Statistically significant at the .10 level; **at the .05 level; ***at the .01 level (two-tailed tests).

fully capture this variation. Human capital measures also had either no association or a weak association with job quality outcomes in the outsourced sample. The organizational variables associated with higher job quality varied somewhat across outcome measures; however, overall, smaller, older, in-bound centers appear to have offered "better jobs."

\section{Discussion}

This study demonstrates that differences in job quality across call center workplaces can be partially explained by national setting, collective bargaining arrangements, and whether call centers are subcontractors or operated in-house. However, these effects vary across the three outcomes measured here: dismissal rate, high-involvement work practices, and performance monitoring. Consistent with Hypothesis 1, call centers in CMEs were more likely to adopt employment practices associated with high job quality than were those in the United States, while call centers in the other LMEs were more similar to those in the United States. However, there were anomalies within each group. Denmark had higher dismissal rates than several CMEs, while both Canada and the United Kingdom had lower dismissal rates than the United States. Call centers in Denmark and France showed more limited use of high-involvement work practices, similar to the LMEs. Performance monitoring was higher in France than in the other CMEs and lower in the United Kingdom than in the other LMEs.

Some of this variation may be due to established institutional differences at the national level. For example, Denmark is known for its unique "flexicurity" model, characterized by weaker employment protections, high levels of unemployment insurance, and active labor market policies, while both Canada and the United Kingdom have stronger employment protection laws than the United States. French industry is also known for relying on a narrower division of labor and for having a weaker tradition of direct worker participation in management decision-making than Germany or Sweden (see, for example, Goyer 2006; Maurice, Sellier, and Silvestre 1986). Other differ- 
Table 5. Unstandardized OLS Estimates for Performance Monitoring. (standard errors in parentheses)

\begin{tabular}{|c|c|c|c|c|c|}
\hline & Model 1 & Model 2 & Model 3 & Model 4 & Outsourced \\
\hline \multicolumn{6}{|l|}{ Collective Bargaining } \\
\hline CME: Union \& WC & & $\begin{array}{c}-0.237 * * * \\
(0.069)\end{array}$ & $\begin{array}{l}-0.174^{* *} \\
(0.069)\end{array}$ & $\begin{array}{c}-0.176^{* *} \\
(0.069)\end{array}$ & $\begin{array}{c}-0.001 \\
(0.117)\end{array}$ \\
\hline CME: WC Only & & $\begin{array}{c}-0.265^{* * *} \\
(0.081)\end{array}$ & $\begin{array}{l}-0.232 * * * \\
(0.081)\end{array}$ & $\begin{array}{l}-0.247 * * * \\
(0.080)\end{array}$ & $\begin{array}{l}-0.382^{* * *} * \\
(0.119)\end{array}$ \\
\hline CME: Union Only & & $\begin{array}{c}-0.111 \\
(0.087)\end{array}$ & $\begin{array}{c}-0.079 \\
(0.086)\end{array}$ & $\begin{array}{c}-0.079 \\
(0.086)\end{array}$ & $\begin{array}{c}-0.123 \\
(0.140)\end{array}$ \\
\hline LME: Union & & $\begin{array}{c}-0.097^{*} \\
(0.053)\end{array}$ & $\begin{array}{c}-0.058 \\
(0.053)\end{array}$ & $\begin{array}{c}-0.047 \\
(0.053)\end{array}$ & $\begin{array}{c}-0.154 \\
(0.133)\end{array}$ \\
\hline \multicolumn{6}{|l|}{ Country } \\
\hline Austria & $\begin{array}{l}-0.575^{* * *} \\
(0.074)\end{array}$ & $\begin{array}{l}-0.418^{* * *} \\
(0.089)\end{array}$ & $\begin{array}{l}-0.484^{* * * *} \\
(0.089)\end{array}$ & $\begin{array}{l}-0.532 * * * \\
(0.090)\end{array}$ & $\begin{array}{l}-0.497^{* * *} \\
(0.151)\end{array}$ \\
\hline Denmark & $\begin{array}{c}-0.519 * * * \\
(0.071)\end{array}$ & $\begin{array}{c}-0.384 * * * \\
(0.082)\end{array}$ & $\begin{array}{l}-0.439 * * * \\
(0.082)\end{array}$ & $\begin{array}{l}-0.408 * * * \\
(0.083)\end{array}$ & $\begin{array}{l}-0.566^{* * *} \\
(0.162)\end{array}$ \\
\hline France & $\begin{array}{l}-0.415^{* * *} \\
(0.052)\end{array}$ & $\begin{array}{c}-0.213^{* * *} \\
(0.078)\end{array}$ & $\begin{array}{l}-0.287^{* * *} \\
(0.078)\end{array}$ & $\begin{array}{l}-0.219 * * * \\
(0.080)\end{array}$ & $\begin{array}{c}-0.246 \\
(0.150)\end{array}$ \\
\hline Germany & $\begin{array}{l}-0.588^{* * * *} \\
(0.059)\end{array}$ & $\begin{array}{l}-0.464 * * * \\
(0.068)\end{array}$ & $\begin{array}{l}-0.583^{* * * *} \\
(0.071)\end{array}$ & $\begin{array}{l}-0.626^{* * *} \\
(0.072)\end{array}$ & $\begin{array}{l}-0.641 * * * \\
(0.109)\end{array}$ \\
\hline Sweden & $\begin{array}{l}-0.527^{* * *} \\
(0.062)\end{array}$ & $\begin{array}{l}-0.349 * * * \\
(0.095)\end{array}$ & $\begin{array}{l}-0.422 * * * \\
(0.095)\end{array}$ & $\begin{array}{l}-0.382 * * * \\
(0.095)\end{array}$ & $\begin{array}{l}-0.501 * * * \\
(0.182)\end{array}$ \\
\hline Canada & $\begin{array}{c}-0.011 \\
(0.045)\end{array}$ & $\begin{array}{c}0.003 \\
(0.045)\end{array}$ & $\begin{array}{c}-0.054 \\
(0.045)\end{array}$ & $\begin{array}{c}-0.001 \\
(0.048)\end{array}$ & $\begin{array}{c}0.020 \\
(0.098)\end{array}$ \\
\hline U.K. & $\begin{array}{l}-0.209 * * * \\
(0.058)\end{array}$ & $\begin{array}{l}-0.168^{* * *} \\
(0.061)\end{array}$ & $\begin{array}{l}-0.205^{* * *} \\
(0.061)\end{array}$ & $\begin{array}{l}-0.182^{* * * *} \\
(0.061)\end{array}$ & $\begin{array}{l}-0.323^{* * *} \\
(0.121)\end{array}$ \\
\hline \multicolumn{6}{|l|}{ Subcontracting } \\
\hline In-House & & & $\begin{array}{l}-0.200^{* * *} \\
(0.037)\end{array}$ & $\begin{array}{l}-0.182 * * * \\
(0.037)\end{array}$ & \\
\hline \multicolumn{6}{|l|}{ Human Capital Controls } \\
\hline Edu: $<18$ & & & & $\begin{array}{c}-0.111 * * * \\
(0.041)\end{array}$ & $\begin{array}{c}-0.150^{*} \\
(0.077)\end{array}$ \\
\hline Edu: University & & & & $\begin{array}{c}-0.170^{* * *} \\
(0.047)\end{array}$ & $\begin{array}{c}-0.109 \\
(0.098)\end{array}$ \\
\hline Weeks to Be Proficient & & & & $\begin{array}{c}-0.002 * * * \\
(0.001)\end{array}$ & $\begin{array}{c}0.001 \\
(0.002)\end{array}$ \\
\hline
\end{tabular}

ences are more difficult to explain, such as the finding that call centers in the United Kingdom use less intensive monitoring than those in Canada and the United States. Taken together, these findings suggest that a simple distinction between economic models does not capture the range of institutional factors that influence job quality in these service workplaces: the United Kingdom is more similar to continental European countries than to the United States or Canada across several outcomes, and high-involvement management may be a feature of only a few countries in Europe rather than a general characteristic of CMEs. The nature of and explanations for these cross-national differences are best explored through further case study analysis.

Collective bargaining arrangements within each group of countries also had different effects across the three outcome variables, providing partial support for Hypotheses 2 and 3. The joint presence of a union and a works council agreement in CMEs was as- 
Table 5. Continued.

\begin{tabular}{lccccc}
\hline & Model I & Model 2 & Model 3 & Model 4 & Outsourced \\
\hline Organizational Controls & & & & & \\
Inbound & $-0.367^{* * *}$ & $-0.325^{* * *}$ & $-0.274^{* * *}$ & $-0.269^{* * *}$ & $-0.376^{* * *}$ \\
& $(0.037)$ & $(0.039)$ & $(0.040)$ & $(0.040)$ & $(0.057)$ \\
Large Business & $-0.149^{* * *}$ & $-0.161^{* * *}$ & $-0.177^{* * *}$ & $-0.164^{* * *}$ & -0.069 \\
& $(0.037)$ & $(0.037)$ & $(0.037)$ & $(0.037)$ & $(0.058)$ \\
Telecom & -0.064 & -0.053 & -0.035 & -0.011 & -0.099 \\
& $(0.039)$ & $(0.039)$ & $(0.039)$ & $(0.039)$ & $(0.078)$ \\
Banking & -0.021 & -0.014 & -0.013 & -0.009 & -0.008 \\
& $(0.036)$ & $(0.036)$ & $(0.036)$ & $(0.036)$ & $(0.063)$ \\
Employment (In) & $0.145^{* * *}$ & $0.150^{* * *}$ & $0.139^{* * *}$ & $0.136^{* * *}$ & $0.136^{* * *}$ \\
& $(0.011)$ & $(0.011)$ & $(0.011)$ & $(0.011)$ & $(0.020)$ \\
Age & $-0.093^{* * *}$ & $-0.088^{* * *}$ & $-0.082^{* * *}$ & $-0.075^{* * *}$ & $-0.139^{* * *}$ \\
& $(0.023)$ & $(0.023)$ & $(0.023)$ & $(0.023)$ & $(0.045)$ \\
Constant & 0.136 & 0.068 & $0.227 * *$ & $0.313^{* * *}$ & $0.486^{* * *}$ \\
& $(0.094)$ & $(0.095)$ & $(0.099)$ & $(0.101)$ & $(0.183)$ \\
Number of Observations & 1,629 & 1,622 & 1,622 & 1,622 & 502 \\
F Ratio & $49.01^{* * *}$ & $38.98^{* * *}$ & $39.14^{* * *}$ & $35.00^{* * *}$ & $13.00^{* * *}$ \\
R-Square & 0.28 & 0.29 & 0.31 & 0.31 & 0.35 \\
Adj. R-Squared & 0.28 & 0.28 & 0.30 & 0.31 & 0.32 \\
F for Change in $\mathrm{R}^{2 a}$ & $34.98^{* * *}$ & $3.07^{* *}$ & $27.11^{* * *}$ & $3.97^{* * *}$ & - \\
\hline
\end{tabular}

${ }^{2}$ Change in $\mathrm{R}^{2}$ in Model 1 is based on the addition of country variables to a model with organizational controls only.

*Statistically significant at the .10 level; **at the .05 level; ***at the .01 level (two-tailed tests).

sociated with lower dismissal rates, greater use of high-involvement work practices, and lower performance monitoring, while in LMEs union presence only affected dismissal rates. Thus, consistent with past research, our findings suggest that strong bargaining rights exercised through dual representation in CMEs may encourage higher levels of participation and discretion (Turner 1991) and also may make it more difficult for employers to dismiss employees, possibly by providing additional mechanisms to challenge hire and fire decisions. In LMEs, unions play a more central role in providing protections from dismissals but do not have the bargaining rights or power to influence work design.

We also found some variation in the effects of different bargaining structures in the CMEs. Most notably, call centers with a works council alone adopted less intensive performance monitoring but showed no difference in terms of dismissals or work practices, while union presence alone was not associated with any of the outcome measures. This is probably explained by the strong ability of works councils in most European CMEs to block invasive and frequent performance monitoring, based on their legal rights and traditional bargaining role, as well as the importance this issue holds for workers (Doellgast 2008:312). Work design, in contrast, is not typically a mandatory subject of bargaining, and thus may require unions to provide expertise, to exercise additional countervailing power, and to play a coordinating role in negotiations. Certain issues in work design, such as teams and flexible working time, have been strongly backed by European unions and continue to shape their political agenda in the workplace.

A third set of findings concerns the effects of outsourcing on job quality and collective bargaining. Outsourced firms had higher dismissal rates and more intensive performance monitoring, providing partial confirmation of Hypothesis 4; however, they were not less likely to use high-involvement work practices. This presents a potentially contradictory picture, as we might have expected some trade-off between the two: employers that use more intensive monitoring should in turn be less likely to invest in practices that require greater employee involvement 
and skill. Our findings suggest that the two outcomes may instead be driven by different organizational or strategic factors. It is likely that a higher level of monitoring is demanded by an outsourcer's clients who are interested in greater transparency of performance results, but that these employers still experiment with team work and flexible working arrangements to boost motivation and performance. In addition, inclusion of outsourced status in the models diminished the size of union and works council effects on dismissals and the size and significance of dual representation effects and union effects in LMEs on performance management. This suggests that some of the variation in outcomes across call centers with different bargaining arrangements can be explained by the larger proportion of in-house centers that are covered by these arrangements.

We also were interested in examining whether the relationships between institutional context and job quality found in the full dataset held for the subsample of subcontractors, as one justification for outsourcing may be to avoid the constrain ts of institutions such as strong union agreements or training obligations. First, the findings show a similar pattern of variation across countries, with generally higher job quality in the CMEs than the LMEs. There is thus no straightforward evidence of cross-national convergence in subcontractors' employment practices, despite their overall higher dismissal rates and more intense use of performance monitoring.

Second, collective bargaining was also associated with some variation in outcomes in outsourced call centers, although here findings differed markedly from those in the full dataset. Both dual bargaining and a union agreement alone in CMEs predicted dismissals, while a union agreement in LMEs had no effect. This may be due to weaker compliance with employment protection rules in this sector, and thus the need for unions to enforce the rules in outsourced workplaces in CMEs. In contrast, unions in LMEs may have achieved weaker job security provisions in subcontractors than in in-house firms. A particularly interesting finding is the strong negative association between works council presence in CMEs and performance monitoring. This suggests that monitoring is one key area in which works councils are able to use bargaining rights to influence outcomes in subcontractors, despite often being newer and less experienced. Thus, while a smaller proportion of subcontractors was covered by collective bargaining, where bargaining was present in CMEs it appears to have made some contribution to higher job quality. However, the strongest manifestations of bargaining's influence appear to have been reduced dismissals and curtailed surveillance rather than participation in higher-quality job design.

The results should be viewed in the light of limitations in the data. First, samples were constructed and surveys administered differently across countries (see Batt et al., in this symposium). This may mean that some cross-national differences are due to the unique characteristics of the centers surveyed. We have tried to address this potential problem by including a comprehensive set of controls in our models, but this may not account for other sources of sampling variation. Second, questions concerning employment practices may not capture differences in design and implementation. The history and interpretation of self-managed teams and flexible working arrangements differ across countries, and formal practices may be implemented differently in union and non-union workplaces. Further analysis using matched pair case studies would provide insights into variation in substantive outcomes and the mechanisms through which collective bargaining influences management practices in different national settings.

\section{Conclusions}

Unions have traditionally been among the most visible organizations working to improve job quality in industrialized countries. Industrial relations scholars have argued that their success is linked to national labor laws and bargaining rights, which give them resources to build countervailing power in negotiations and thus to incorporate stakeholder interests in firms' investment and management decisions (Turner 1991). Comparative capitalism theories have treated collective bargaining 
as one element of national business systems or varieties of capitalism, and argued that distinct employer strategies in European coordinated market economies are associated with greater investments in employees (Hall and Soskice 2001).

The findings presented here provide evidence that the configuration of national institutions in European coordinated market economies provides incentives and constraints that can encourage managers to adopt practices associated with higher-quality jobs, even in more poorly regulated call center workplaces. However, the strength and presence of collective bargaining appear to play an important role within these countries in improving worker discretion and participation, despite increasing variation in bargaining structures at the workplace level. Outsourced call centers provide a lower cost and potentially a more flexible option for organizing jobs, but do not represent a comprehensive escape from regulation. At the same time, outsourcing to some extent assists management prerogative in both coordinated and liberal market economies, in the sense that both the presence of collective bargaining and its influence are more limited in these workplaces.

These findings have important implications for how governments and other collective actors approach the expansion of service work. They suggest that a "high road" is possible, but may require the active maintenance of employment protections and bargaining rights. For unions, the news on these expanding workplaces is not uniformly good. Although unions appear to retain some influence in line with established institutional opportunities and constraints, they would be ill-advised to rely on the stability of these frameworks. Extending their influence into more cost- and market-driven industry segments will require considerable creativity in adapting traditional forms of bargaining leverage to new challenges.

\section{REFERENGES}

Abraham, Katharine. 1990. "Restructuring the Employment Relationship: The Growth of Market-Mediated Work Arrangements." In Katharine Abraham and Robert McKersie, eds., New Developments in the Labor Market: Towarda New Institutional Paradigm. Cambridge, Mass.: MIT Press.

Appelbaum, Eileen, and Rosemary Batt. 1994. The New American Workplace: Transforming Work Systems in the United States. Ithaca, N.Y.: ILR Press (an imprint of Cornell University Press).

Batt, Rosemary. 1999. "Work Organization, Technology, and Performance in Customer Service and Sales." Industrial and Labor Relations Review, Vol. 52, No. 4, pp. 539-64.

Batt, Rosemary, Virginia Doellgast, and Hyunji Kwon. 2006. "Service Management and Employment Systems in U.S. and Indian Call Centers." In Susan M. Collins and Lael Brainard, eds., Offshoring White-Collar Work. Washington, D.C.: Brookings Institution Press.

Becker, Gary S. 1964. Human Capital. New York: Columbia University Press.

Belanger, Jacques, Anthony Giles, and Gregor Murray. 2002. "Towards a New Production Model: Potentialities, Tensions, and Contradictions." In Gregor Murray, Jacques Belanger, Anthony Giles, and Paul-Andre Lapointe, eds., Work and Employment Relations in the High Performance Workplace, pp. 15-71. London: Continuum. Berggren, Christian. 1992. Alternatives to Lean Production:
Work Organization in the Swedish Auto Industry. Ithaca, N.Y: ILR Press.

Blutner, Doris, Hanns-Georg Brose, and Ursula Holtgrewe. 2000. "Vertriebshandeln und Organisationsstruktur." In Heiner Minssen, ed., Begrenzte Entgrenzungen. Wandlungen von Organisation und Arbeit, Pp. 141-62. Berlin: Sigma.

Colvin, Alex. 2006. "Flexibility and Fairness in Liberal Market Economies: The Comparative Impact of the Legal Environment and High-Performance Work Systems." British Journal of Industrial Relations, Vol. 44, No. 1, pp. 73-97.

Cully, Mark, Stephen Woodland, Andrew O'Reilly, and Gill Dix. 1999. Britain at Work: As Depicted by the 1998 Workplace Employee Relations Survey. London: Routledge. Delery, John E. 1998. "Issues of Fit in Strategic Human Resource Management: Implications for Research." Human Resource Management Review, Vol. 8, No. 3, pp. 289-309.

Doellgast, Virginia. 2008. "Collective Bargaining and High Involvement Management in Comparative Perspective: Evidence from US and German Call Centers." Industrial Relations, Vol. 47, No. 2, pp. 284-319.

Doellgast, Virginia, and Ian Greer. 2007. "Vertical Disintegration and the Disorganization of German Industrial Relations." British Journal of Industrial Relations, Vol. 45, No. 1, pp. 55-76.

Dolvik, Jon Erik, and Jeremy Waddington. 2004. "Or- 
ganizing Marketized Services: Are Trade Unions up to the Job?" Economic and Industrial Democracy, Vol. 25, No. 1, pp. 9-40.

Finegold, David, Karin Wagner, and Geoff Mason. 2000. "National Skill-Creation Systems and Career Paths for Service Workers: Hotels in the United States, Germany, and the United Kingdom." International Journal of $\mathrm{Hu}$ man Resource Management, Vol. 11, No. 3, pp. 497-51.

Godard, John. 2002. "Institutional Environments, Employer Practices, and States in Liberal Market Economies." Industrial Relations, Vol. 41, No. 2, pp. 249-86.

Goyer, Michel. 2006. "Varieties of Institutional Investors and National Models of Capitalism: The Transformation of Corporate Governance in France and Germany." Politics and Society, Vol. 34, No. 3, pp. 399-430.

Green, Francis. 2005. Demanding Work: The Paradox of Job Quality in the AffluentEconomy. Princeton: Princeton University Press.

Grugulis, I., S. Vincent, and G. Hebson. 2003. "The Future of Professional Work? The Rise of the Network Form and the Decline of Discretion." Human Resource Management Journal, Vol. 13, No. 2, pp. 45-59.

Hall, Michael, and Michael Terry. 2004. "The Emerging System of Statutory Worker Representation." In Geraldine Healy, Edmund Heery, Philip Taylor, and William Brown, eds., Future of Worker Representation, pp. 207-28. Basingstoke: Palgrave.

Hall, Peter A., and David Soskice, eds. 2001. Varieties of Capitalism: The InstitutionalFoundations of Comparative Advantage. Oxford: Oxford University Press.

Hammer, Tove, and Ariel Avgar. 2005. "The Impact of Unions on Job Satisfaction, Organizational Commitment, and Turnover." Journal of Labor Research, Vol. 26, No. 2, pp. 241-66.

Harrison, Bennett, and Maryellen Kelley. 1993. "Outsourcing and the Search for Flexibility." Work, Employment and Society, Vol. 7, No. 2, pp. 213-35.

Hoepner, Martin. 2007. "Coordination and Organization: The Two Dimensions of Nonliberal Capitalism." MPIfG Discussion Paper 07/12.

Holman, David, Rosemary Batt, and Ursula Holtgrewe. 2007. "The Global Call Center Report: International Perspectives on Management and Employment." A Report of the Global Call Centre Research Network. Ithaca, N.Y.: Cornell University.

Holst, Hajo. 2008. "The Political Economy of Trade Union Strategies in Austria and Germany: The Case of Call Centres." European Journal of Industrial Relations, Vol. 14, No. 1, pp. 25-45.

Jackson, Gregory, and Richard Deeg. 2006. "How Many Varieties of Capitalism? Comparing the Comparative Institutional Analyses of Capitalist Diversity." Max Planck Institute for the Study of Societies Discussion Paper 06/2.

Jørgensen, Carsten. 2003. "Thematic Feature-Works Councils and Other Workplace Employee Representation and Participation Structures." European Industrial Relations Observatory Online (EIRO), http://www.eiro.eurofound.eu.int $/ 2003 / 09 /$ tfeature/dk0309102t.html.

Kalleberg, Arne L., Barbara F. Reskin, and Ken Hudson. 2000. "Bad Jobs in America: Standard and Nonstandard Employment Relations and Job Quality in the
United States." American Sociological Review, Vol. 65, No. 2, pp. 256-78.

Katz, Harry, and Owen Darbishire. 2000. Converging Divergences. Ithaca, N.Y.: IL.R Press (an imprint of Cornell University Press).

Korczynski, Marek. 2002. Human Resource Management in Service Work. London: Palgrave.

Lorenz, Edward H. 1992. "Trust and the Flexible Firm: International Comparisons." Industrial Relations, Vol. 31, No. 3, pp. 455-72.

Maddala, G.S. 1992. Introduction to Econometrics, 2nd ed. New York: Macmillan.

Marginson, Paul, Keith Sisson, and James Arrowsmith. 2003. "Between Decentralization and Europeanization: Sectoral Bargaining in Four Countries and Two Sectors." European Journal of Industrial Relations, Vol. 9. No. 2, pp. 163-87.

Maurice, Mark, Francois Sellier, and Jean-Jacques Silvestre. 1986. The Social Foundations of Industrial Power. Cambridge, Mass.: MIT Press.

McGovern, Patrick, Deborah Smeaton, and Stephen Hill. 2004. "Bad Jobs in Britain: Nonstandard Employment and Job Quality." Work and Occupations, Vol. 31, No. 2, pp. 225-49.

Pfeffer, Jeffrey, and James Baron. 1988. "Taking the Workers Back Out: Recent Trends in the Structuring of Employment." Research in Organizational Behavior, Vol. 10, No., pp. 257-303.

Schönauer, Annika. 2008. "Reorganising the Front Line: The Case of Public Call Centre Services." Work, Organisation, Labour and Globalisation, Vol. 2, No. 2, pp. 131-47.

Shaw, Jason D., John E. Delery, G. Douglas Jenkins, Jr., and Nina Gupta. 1998. "An Organization-Level Analysis of Voluntary and Involuntary Turnover." Academy of Management Journal, Vol. 41, No. 5, pp. 511-25.

Shire, Karen, Ursula Holtgrewe, and Christian Kerst. 2002. "Re-Organising Customer Service Work: An Introduction." In Ursula Holtgrewe, Christian Kerst, and Karen Shire, eds., Re-Organising Service Work: Call Centres in Germany and Britain, pp. 1-16. Aldershot: Ashgate.

Streeck, Wolfgang. 1984. Industrial Relations in West Germany: A Case Study of the Car Industry. London: Heinemann.

1991. "On the Institutional Conditions of Diversified Quality Production." In Egon Matzner and Wolfgang Streeck, eds., Beyond Keynesianism: The SocioEconomics of Production and Full Employment, pp. 21-61. Aldershot: Edward Elgar.

Streeck, Wolfgang, and Kathleen Thelen, eds. 2005. Beyond Continuity: Institutional Change in Advanced Political Economies. Oxford: Oxford University Press.

Sydow, Jörg. 1997. Mitbestimmung und neue Unternehmungsnetzwerke. Gütersloh: Hans Böckler Stiftung.

Taylor, P., and P. Bain. 2001. "Trade Unions, Workers' Rights, and the Frontier of Control in UKCall Centres." Economic and Industrial Democracy, Vol. 22, pP. 39-66.

Thelen, Kathleen. 1991. Union of Parts: Labor Politics in Postwar Germany. Ithaca: Cornell University Press.

Tilly, Chris. 1997. "Arresting the Decline of Good Jobs in the USA?" Industrial Relations Journal, Vol. 28, No. 4, pp. 269-74. 
Turner, Lowell. 1991. Democracy at Work: Changing World Markets and the Future of Labor Unions. Ithaca: Cornell University Press.

Valverde, Mireia, Gerard Ryan, and María Tatiana Gorjup. 2007. "An Examination of the Quality of Jobs in the Call Center Industry." International Advances in Economic Research, Vol. 13, No. 2, pp. 146-56.

Walsh, Janet, and Stephen Deery. 2006. "Refashioning Organizational Boundaries: Outsourcing Customer Service Work." Journal of Management Studies, Vol. 43, No. 3, pp. 557-82.
Wever, Kirsten S. 1995. Negotiating Competitiveness: Employment Relations and Organizational Innovation in Germany and the United States. Boston: Harvard Business School Press.

Whitley, Richard. 1999. Divergent Capitalisms: The Social Structuring and Change of Business Systems. Oxford: Oxford University Press.

Wood, Stephen. 1996. "High Commitment Management and Unionization in the U.K." International Journal of Human Resource Management, Vol. 7, No. 1 , pp. 41-58. 